Piotr Tomski ${ }^{1}$

\title{
SIEĆ SPOŁECZNA JAKO POTENCJAŁ PRZEDSIĘBIORCY DETERMINUJĄCY EFEKTYWNOŚĆ FIRMY
}

Streszczenie: Celem niniejszego rozdziału jest prezentacja znaczenia potencjału przedsiębiorcy, który wynika z potencjału sieci osobistych stanowiących jednocześnie czynnik determinujący wielowymiarowo postrzeganą efektywność przedsiębiorstwa.

Słowa kluczowe: sieć społeczna, sieć osobista, kontakty, komunikacja, przedsiębiorczość, efektywność, wzrost, rozwój.

\section{Wprowadzenie}

Jak skonstatowali N.F. Norris i D.V. Brazeal (1994), zanim pojawi się przedsiębiorczość konieczne jest zaistnienie potencjału dla przedsiębiorczości, niezależnie czy dotyczy to potencjału dla tworzenia nowych przedsięwzięć czy też innowacji i wzrostu w już istniejących podmiotach. Potencjał dla przedsiębiorczości wymaga potencjalnych przedsiębiorców. W literaturze zwraca się w tym kontekście uwagę na zagadnienie intencji, teorię planowanych zachowań oraz teorię zdarzenia przedsiębiorczego. Sugestie Norris'a i Brazeala, opublikowane we wpływowym czasopiśmie "Entrepreneurship Theory and Practice", dotyczące potencjału dla przedsiębiorczości, wiodą ewidentnie ku potencjałowi niesionemu przez człowieka przedsiębiorcę. Zarządzanie potencjałem ludzkim bowiem, jak stwierdza J. Penc (2010), łączy się przede wszystkim z pytaniem o istotę kapitału ludzkiego i jego doskonalenie oraz reguły odnoszące się do jego formowania i rozwoju. Kapitał ludzki to ludzie z ich wiedzą i umiejętnościami, doświadczeniem zawodowym, aspiracjami, motywacjami i postawami, to powiązania, relacje i stosunki między nimi, poziom zaufania i wzajemnych relacji, a także obowiązująca kultura. Jak każdy kapitał, także i ludzki stanowi aktywa zdolne do generowania wartości. Kapitał ludzki zatem postrzega się jako niezwykle cenny zasób, dzięki któremu można tworzyć określony strumień korzyści bądź w znaczącym stopniu może on przyczynić się do ich wygenerowania.

Potencjał ludzki rozumiany przez pryzmat kapitału ludzkiego to, oprócz potencjału kapitału emocjonalnego i intelektualnego, także potencjał kapitału społecznego. W tym kontekście warto zwrócić uwagę na wpływ potencjału ludzkiego

\footnotetext{
${ }^{1}$ dr hab. inż., Prof. PCz, Politechnika Częstochowska, piotr.tomski@ gmail.com
} 
(potencjału przedsiębiorcy), utożsamianego z kapitałem społecznym, a precyzując problem, utożsamianego z sieciami powiązań, w których uczestniczy przedsiębiorca, na efektywność firmy. Uczestnictwo w owych sieciach postrzegać można jako niezwykle istotny wątek zarówno $\mathrm{w}$ perspektywie teorii jak i praktyki przedsiębiorczości. Jak skonstatował bowiem M. Bratnicki (2004), z perspektywy konstruktywizmu metodologicznego przedsiębiorcy są uczestnikami złożonych sieci, które formują wraz z innymi osobami. Kluczem do przedsiębiorczości zaś staje się funkcjonowanie mentalne i aktywne porozumiewanie się w sytuacjach lokalnych, które zachodzi na bieżąco, w przepełnionej życiem teraźniejszości. Wspomniana, przepełniona życiem teraźniejszość przedsiębiorcy niesie ze sobą istnienie nieustannych interakcji międzyludzkich, dzięki którym przedsiębiorca pozyskuje informacje i wiedzę niezbędne do realizacji procesu przedsiębiorczego zarządzania, opartego na rozpoznawaniu i eksploatacji szans. Zdaniem J. Stachowicza (2015), zasadne jest wręcz aby przedsiębiorczość definiować, dyskutować i oceniać jako proces ukonstytuowany w sieci działań ludzi. Uznanie roli człowieka w organizacji, jako centrum wszelkich planowanych przeobrażeń postrzegania i rozumienia organizacji oraz jej rozwoju, przyczyniło się do ukształtowania nurtu badań nad przedsiębiorczością, w szczególności uwzględniającego psychologiczne, kognitywistyczne oraz aksjologiczne czynniki tego zjawiska. Warto w tym kontekście zgodzić się ze stwierdzeniem, iż kapitał społeczny stał się uznanym fenomenem (i czynnikiem racjonalizacji ludzkich działań) dla spożytkowania silnych stron współpracy ludzi w przedsięwzięciach gospodarczych i społecznych (STACHOWICZ 2015).

W kontekście powyższych konstatacji, celem niniejszego opracowania jest prezentacja znaczenia potencjału przedsiębiorcy, który wynika z potencjału sieci osobistych stanowiących jednocześnie czynnik determinujący wielowymiarowo postrzeganą efektywność przedsiębiorstwa.

\section{Istota sieci osobistej przedsiębiorcy}

Sieci społeczne zajmują szczególne miejsce we współczesnej teorii i praktyce zarządzania przedsiębiorstwem. Jak podkreśla bowiem B. Nogalski i P. Niewiadomski (2014), współczesne przedsiębiorstwo to obiekt umieszczony w zachodzących na siebie i wzajemnie uzależnionych relacjach w układzie społecznym, ekonomicznym, przestrzennym, technologicznym i politycznym.

Sieć społeczna może zostać określona jako zbiór węzłów (np. osób, organizacji), połączonych zbiorem relacji społecznych (LAUMANN, GALASKIEWICZ I MARSDEN 1978). Zdefiniować można ją także jako „rzeczywisty zbiór powiazań pomiędzy zbiorem osób" (MITCHELL 1973) lub ,zestaw więzi tączacych kilku aktorów”" 
(NELSON 1988) czy też układ węzłów lub aktorów (CASTILLA, HwANG, GRANOVETTER I GRANOVETTER 2000).

Wszelkie obiekty społeczne, traktowane jako elementy sieci, określa się mianem aktorów, zdolnych do wzajemnych oddziaływań i wchodzenia we wzajemne stosunki (KWAŚNIEWICZ 1998). Sieć społeczna jest zatem strukturą społeczną, tworzoną przez zespół aktorów (np. ludzi, organizacji), połączonych siecią wzajemnych powiązań. Aktorzy połączeni są za pomocą więzi, które stanowią kategorię nadrzędną wobec relacji (OLESIŃSKI 2010). Gdy sieć społeczna analizowana jest z perspektywy jednego aktora społecznego, co jednocześnie implikuje umieszczenie go w centrum sieci (jednostka - ego - znajduje się w centrum sieci), sieć taką określa się mianem sieci egocentrycznej bądź sieci personalnej lub osobistej. Sieć osobista nazywana jest także siecią egocentryczną (ego-centered, ego-centric). Stanowi ona zbiór osób połączonych z konkretną osobą (ego), która to osoba stanowi jednocześnie punkt ogniskowania, bądź, inaczej, zakotwiczenia sieci. Analizując położenie w sieci i splot powiązań ego, warto przyjąć, iż punkt ten stanowi osoba przedsiębiorcy.

Sieć osobistą zdefiniować można też jako sieć, w której skład wchodzą wszystkie osoby kontaktowe, z którymi dana jednostka pozostaje w określonych relacjach (SŁAWECKI 2011). Osobista sieć przedsiębiorcy określana jest także w literaturze jako sieć przedsiębiorcza (entrepreneurial network) (GREVE 2003). Sieci osobiste przedsiębiorcy są, jak podkreślają L. Hamill i N. Gilbert (2010), obrazem relacji między osobą i innymi osobami: przyjaciółmi, rodziną, znajomymi, współpracownikami itd. Sieć społeczna przedsiębiorcy stanowi zaś agregację sieci osobistych.

Sieci społeczne postrzega się jako scaloną całość związków emocjonalnych i fizycznych. Uznaje się, iż gęstość, osiągalność i stopień dywersyfikacji sieci determinują strukturę czasoprzestrzenną, $\mathrm{w}$ zakresie której przedsiębiorcy mogą komunikować się między sobą (DUBINI I ALDRICH 1991). Tworzone przez przedsiębiorcę sieci składają się zarówno z relacji biznesowych, jak i różnego rodzaju innych powiązań (JÄMSÄ, TÄHTINEN, RYAN I PALLARI 2012), które wpływają na funkcjonowanie przedsiębiorstwa.

Podejmując próbę spojrzenia na sieci osobiste przez pryzmat ich utylitarnego charakteru, przytoczyć można S. Gudkovą (2008), która zwraca uwagę na wyodrębnienie trzech obszarów: prywatnego, efektywnego i rozszerzonego. Do obszaru prywatnego należą osoby, z którymi centralna jednostka utrzymuje bliskie relacje, takie jak członkowie rodziny, krewni, przyjaciele. W obszarze efektywnym znajdują się jednostki, z którymi ego łączą znacznie luźniejsze więzi, czemu jednocześnie towarzyszą mniejsze oczekiwania ego wobec tych osób. Do obszaru rozszerzonego należą osoby, z którymi ego nie utrzymuje bezpośrednich relacji, korzystając $\mathrm{z}$ tych kontaktów poprzez pośredniczące osoby trzecie. 


\section{Ogólna rola sieci społecznej}

Odwołując się do dokonań K. Polanyiego (2010), M. Granovetter (1985) postawił tezę, zgodnie z którą istotna część transakcji zawieranych na rozwiniętych rynkach w systemie kapitalistycznym odbywa się za pośrednictwem relacji społecznych. Zakorzenienie działania ekonomicznego nie jest zatem, jak uważa między innymi K. Polanyi, wyłącznie cechą społeczeństw przedrynkowych (BARBER 1995). Według teorii zakorzenienia, aktorzy nie działają i nie podejmują decyzji jak odizolowane atomy, poza społecznym kontekstem, ale jednocześnie nie dostosowują się w niewolniczy sposób do scenariuszy napisanych dla nich przez kategorie społeczne, które są im dane. Podejmowane przez nich próby realizacji działań celowych są zakorzenione $\mathrm{w}$ konkretnych, istniejących systemach relacji społecznych (GRANOVETTER 1985). Każde z działań ekonomicznych ma zatem swoją historię i jest wyznaczane przez strukturę relacji społecznych. Zakorzenienie to, zwane zakorzenieniem strukturalnym, polega na kontekstualizcji wymiany ekonomicznej w uporządkowane relacje interpersonalne (DIMAGGIO I ZUKIN 1990). Wynika z tego, iż społeczne struktury mogą aktywnie oddziaływać na różne obszary gospodarki.

Ważną próbę rozwinięcia koncepcji zakorzenienia strukturalnego w odniesieniu do przedsiębiorstw, opierając się na wynikach badań wśród firm nowojorskiego, ekskluzywnego przemysłu odzieżowego, podjął B. Uzzi (1996). Starał się on zdefiniować zakorzenienie strukturalne, zidentyfikować jego główne cechy, źródła i konsekwencje $\mathrm{w}$ odniesieniu do podmiotów gospodarczych, a także przenieść opisywaną ideę z wymiaru teoretycznego w praktyczny, pokazując, jak może ona oddziaływać na efekty działania ekonomicznego. W jego ujęciu strukturalne zakorzenienie dotyczy struktury sieci i jakości więzi między podmiotami. Jest to cecha systemu wymiany i ram działania ekonomicznego, które kierują się logiką odmienną niż rynkowa. Zdaniem B. Uzziego każda organizacja dysponuje dwoma rodzajami relacji (tworzących sieci) z otoczeniem: na zasadach rynkowych (arm's length) i zakorzenienia (embedded). Pierwsze z nich to typowe transakcje rynkowe. Mają one charakter krótkoterminowy i luźny oraz funkcjonują bez rozszerzonego kontaktu społecznego czy personalnego. Odznaczają się one także znacznym stopniem zmienności (duża rotacja podmiotów nawiązujących kontakt). W tym przypadku wzorce wymiany między stronami wyznaczane są przez funkcjonowanie mechanizmu rynkowego pozwalającego na ustalenie cen. Istotą relacji drugiego rodzaju (więzi zakorzenione) jest określanie wzorców wymiany przez sieć. Kontakty między podmiotami w tym przypadku są powtarzane i oparte na oczekiwaniach oraz dyspozycjach ukształtowanych przez więzi. Funkcją relacji zakorzenionej jest wytwarzanie zaufania, ułatwiającego wymianę informacji (norma wzajemności, pozytywne interpretacje zachowania i intencji innych podmiotów), pełnienie roli 
środka (kanału) wymiany ważnych zasobów z punktu widzenia działalności gospodarczej oraz podstawy do wspólnego rozwiązywania problemów.

Konsekwencje funkcjonowania podmiotów opartych na zakorzenionych więziach mają charakter ekonomiczny. Umożliwiają one dostęp do nowych wymian, redukują koszty działalności (wzajemne zaufanie sprawia, że niepotrzebny jest nadzór) oraz pozwalają zdobywać doświadczenie i wiedzę (wzrost zdolności adaptacyjnych firm). Tym samym jakość relacji i jej struktura powinny przekładać się na możliwości funkcjonowania firmy na rynku (zdolności do utrzymania firmy).

\section{Rola sieci społecznej przedsiębiorcy w generowaniu przesłanek dla wzrostu efektywności przedsiębiorstwa}

W literaturze znaleźć można stwierdzenia, iż relacje jednostek ludzkich w sieciach są znaczące dla funkcjonowania organizacji (np. BURT 1995) i jej sukcesu (HUNING, BRYANT I HOLT 2015). Analiza literatury przedmiotu wiedzie wręcz do stwierdzenia, iż sieci społeczne to kanwa dla struktur organizacyjnych wspomagających wszelką współpracę. Sieci te są jednocześnie czynnikiem wspierającym i dynamizującym procesy poznawcze, co ma szczególne znaczenie także w kontekście przedsiębiorczości, bowiem każdy proces przedsiębiorczości jest procesem poznawczym.

W ogólnym rozumieniu powiązania w rodzaju „przyjaciele przyjaciół” (BOISSEVAIN 1974), zobowiązania grupowe (BOURDIEU 1986) oraz silne i słabe więzi (GRANOVETTER 1973) dostarczają uczestniczącym stronom, należącym do określonych sieci, uprzywilejowaną informację, dostęp do okazji (szans) oraz umożliwiają jednostkom ludzkim pozyskanie zasobów, do których dostęp w „standardowych”, nieusieciowionych warunkach można określić jako trudny (JACK 2005).

Według A.R. Andersona, S.L. Jack i S.D. Dodd (2005) dla przedsiębiorcy koniecznością jest posiadanie licznych, zdywersyfikowanych kontaktów w otoczeniu, do których zaliczyć należy krewnych, przyjaciół i znajomych oraz innych osób, pochodzących z różnych grup społecznych. Odpowiedni dobór składu i utrzymanie tych kontaktów jest, zdaniem tych autorów, centralnym wątkiem przedsiębiorczego życia i może mieć silny wpływ na wyniki i efektywność przedsiębiorstwa.

W badaniach prowadzonych w obszarze przedsiębiorczości istotną pozycję wśród analizowanych czynników zajmuje właśnie relacyjne otoczenie przedsiębiorcy. Sieci społeczne są głównym czynnikiem identyfikacji szans rynkowych (OZGEN I BARON 2007), zaś różnice między przedsiębiorcami w tym wymiarze stanowią celną podstawę dla wyjaśnienia różnic we wzroście przedsiębiorstw (ACQUAAH 2011; STAM I ElFring 2008; VISSA I CHACAR 2009), ich innowacyjności (JULIEN, 
ANDRIAMBELOSON I RAMANGALAHY 2004) i wynikach działalności eksportowej (Ellis 2000; LiANXI, WEI-PING I XUEMING 2007). Fakt ten dotyczy zarówno przedsiębiorczości indywidualnej, jak i organizacyjnej. W 2007 roku J. Watson (2007) udowodnił, iż cechy sieci społecznych menedżerów mają pozytywny wpływ na przetrwanie i wzrost firm. W innych badaniach T. Manolova, N. Carter, I. Manev i B. Gyoshev (2007) udowodnili, iż wartość sieci doradczej zbudowanej wokół dyrektorów naczelnych zwiększa prawdopodobieństwo przyszłego wzrostu firmy. Osobiste relacje dyrektorów naczelnych zostały zidentyfikowane jako kluczowe zarówno w fazie startup'u jak i w trakcie pozostałych faz cyklu życia małego przedsiębiorstwa.

Istnieją wyniki badań wskazujące, iż istnieje pozytywna relacja między poszukiwaniem przez przedsiębiorcę porad na zewnątrz przedsiębiorstwa, a efektywnością małego przedsiębiorstwa, mierzoną jako zysk i wzrost sprzedaży (KENT 1994). W tej samej konwencji pozostają wyniki badań, w których udowodniono, iż interakcja przedsiębiorcy $\mathrm{z}$ otoczeniem firmy (osobami funkcjonującymi $\mathrm{w}$ otoczeniu) jest dodatnio skorelowana $\mathrm{z}$ efektywnością finansową (Dollinger 1985). L. Dyer i C. Ross (2008) wykazali, iż w przypadku małych przedsiębiorstw, częstotliwość poszukiwania informacji o rynku w otoczeniu jest pozytywnie powiązana z sukcesem przedsiębiorstwa. Sukces zaś w przypadku małego przedsiębiorstwa jest ściśle związany $\mathrm{z}$ odczuciami przedsiębiorcy dotyczącymi efektywności realizowanego przez niego przedsięwzięcia. M.A. Hitt, R.D. Ireland, S.M. Camp i D.L. Sexton (2001; 2002) zasugerowali zaś, iż kapitał społeczny dostarcza informacji, wiedzy technologicznej, zapewnia dostęp do rynków oraz komplementarnych zasobów. Stanowi on zatem niezwykle ważny zasób i może wpływać bezpośrednio na efektywność przedsiębiorstwa

Dostępne wyniki badań wskazują, iż interakcja przedsiębiorcy z otoczeniem firmy (osobami funkcjonującymi w otoczeniu) jest dodatnio skorelowana $\mathrm{z}$ efektywnością finansową (DOLlinger 1985). Stwierdzono także, iż istnieje dodatni wpływ częstotliwości kontaktów przedsiębiorcy z członkami jego sieci osobistej na wzrost poziomu sprzedaży (dotyczy nowych firm) (RIPOLLES I BLESA 2005). Więzi z profesjonalistami z branży przyczyniają się do wzrostu sprzedaży i zyskowności (BUTLER, BROWN I CHAMORNMARN 2003). W przypadku małych przedsiębiorstw, częstotliwość poszukiwania informacji o rynku w otoczeniu jest pozytywnie powiązana $\mathrm{z}$ sukcesem przedsiębiorstwa (DYER I ROSS 2008). Istnieje również dodatnia zależność między uczestnictwem w zdywersyfikowanych sieciach, a efektywnością przedsiębiorstwa (wyniki metaanalizy w oparciu o 68 niezależnych procedur badawczych) (RAUCH, ROSENBUSCH, UNGER I FRESE 2016). Bliskie więzi z przedstawicielami władz i instytucji finansowych prowadzą do wzrostu sprzedaży i wzrostu efektywności produkcji (LAU I BRUTON 2011). Stwierdzono również, i także 
wzrost firmy zakorzeniony jest w sieciach przedsiębiorczych i znacząco uzależniony od liczby powiązań (BRINK 2011).

Częstotliwość kontaktów z członkami sieci pozytywnie wpływa na efektywność nowego przedsięwzięcia gospodarczego (WEST I NOEL 2009) oraz osiąganie doskonałości technologicznej (GRANDI I GRIMALDI 2003), a relacje osobiste wspierają sukces kooperacji w innowacjach procesowych (DANIK I ŻUKOWSKA 2011). Zaangażowanie firmy w sieci osobiste wpływa na jej efektywność ekonomiczną i innowacyjną (AHUJA 2000; OWEN-SMITH I POWELl 2004; ROWLEY, BEHRENS I KRACKHARDT 2000).

Relacje z klientami, dostawcami, uczestnictwo w sieci nieformalnej i uczestnictwo w wydarzeniach prowadzi do wzrostu firmy (HoRMIGA, BATISTA-CANINO I SANCHEZ-MEDINA 2011) zaś właściwy dobór kontaktów jest kluczem do efektywności zasobów relacyjnych. Nieformalne porozumienia wynikające z kontaktów osobistych mogą przyspieszyć reakcje na szanse pojawiające się na rynku oraz ograniczyć koszty transakcyjne (SARNOWSKI 2013).

Badania przeprowadzone przez P. Tomskiego (2016) ujawniły, że w przypadku badanej próby ma miejsce pośredniczące działanie efektów informacyjnych sieci osobistej przedsiębiorcy. Działanie to ma miejsce we wszystkich analizowanych konfiguracjach wymiarów sieci i wymiarów efektów informacyjnych w odniesieniu do wszystkich wymiarów efektywności małej firmy. Zidentyfikowano jednak fakt, iż najsilniejszy efekt mediacyjny występuje $\mathrm{w}$ przypadku sieci tworzonej $\mathrm{z}$ osobami spoza rodziny przedsiębiorcy, w warunkach pośredniczącego działania efektów informacyjnych w zakresie zasobów o potencjale dla wykorzystania szans. Wyniki te ukazują, iż w każdym przypadku wpływ sieci osobistej przedsiębiorcy nie jest działaniem bezpośrednim, choć efekt pośredni zależny jest od rodzaju podsieci przedsiębiorcy, wymiaru efektów i wymiaru efektywności. Generalnie, wywarcie wpływu na efektywność przedsiębiorstwa możliwe jest poprzez zaistnienie efektu pośredniczącego $\mathrm{w}$ postaci dostarczenia przedsiębiorcy informacji. W związku z faktem, iż informacje te dotyczą zasobów o potencjale dla wykorzystania szans oraz bezpośrednio szans, stanowią one element prowadzący do zwiększenia efektywności firmy. Pozyskane przez przedsiębiorcę informacje, prowadzą do wykorzystania owych zasobów bądź konkretnych okazji, a fakt ten znajduje swoje odzwierciedlenie we wzroście efektywności. Sieci te zatem bezwzględnie stanowią potencjał przedsiębiorcy determinujący poziom efektywności przedsiębiorstwa.

\subsection{Podsumowanie}

Specyficzną umiejętnością przedsiębiorcy jest tworzenie, utrzymanie i pozyskiwanie informacji z sieci osobistej, która stanowi jego specyficzny potencjał. 
Sieć ta, stanowiąc, jak podkreśla B. Johannisson (1990, s. 41), „najbardziej znaczący zasób firmy", dostarcza przedsiębiorcy informacji odnoszących się do zasobów o potencjale dla wykorzystania szans oraz bezpośrednio dotyczących szans.

Sieci społeczne (sieci osobiste) dostarczają przedsiębiorcom szerokiego wachlarza wartościowych zasobów, niebędących dotychczas w ich posiadaniu, wspierając ich tym samym w osiąganiu celów postawionych przed zarządzanymi przez nich przedsiębiorstwami. Wśród najistotniejszych zasobów, które dostarczane są przedsiębiorcom poprzez sieci osobiste wskazać należy te, które prowadzą do wykorzystania szans, co stanowi jednocześnie rdzeń przedsiębiorczych działań. W związku zaś z faktem, iż różne jednostki w sieci osobistej dostarczają odmiennych zasobów i informacji, wskazane jest, by przedsiębiorca wchodził $w$ interakcje z różnymi osobami (TOMSKI 2016).

Sukces w zarządzaniu małymi i średnimi firmami zależy od czynników, których umiejętne wykorzystanie przyczynia się do ich przetrwania, wzrostu i rozwoju. Centralną postacią w kreowaniu sukcesu małej firmy jest przedsiębiorca, posiadający wiedzę o możliwościach wzmocnienia i spożytkowania zewnętrznych oraz wewnętrznych czynników sukcesu oraz skutecznie je wykorzystujący. Wzmacnianie czynników sukcesu wymaga nieustannej obserwacji otoczenia przedsiębiorstwa pod kątem ujawniania okazji i nowych możliwości (SKALIK 2010; LEMAŃSKA-MAJDZIK I OKRĘGLICKA 2015).

Sprostanie zmianom w otoczeniu i jego turbulencjom może wymagać od przedsiębiorców utrzymania i odpowiedniego dostosowania więzi sieciowych. Więzi te zaś mogą wspomagać przedsiębiorców w procesie pozyskiwania zasobów i wsparcia (QIAN I KEMELGOR 2013).

Aby osiągnąć cele działalności przedsiębiorczej, obejmującej odkrywanie, kreowanie i eksploatację szans (SHANE I VENKATARAMAN 2000; VENKATARAMAN 1997), często niezbędne jest właśnie wykorzystanie sieci profesjonalnych i osobistych przedsiębiorcy (LECHNER, DOWLING I WELPE 2006), które mogą wnosić istotny wkład w bazę zasobową przedsięwzięcia, poprzez umożliwienie pozyskania zasobów finansowych i ludzkich (FLORIN, LUBATKIN I SCHULZE 2003).

Reasumując rozważania przedstawione w niniejszym opracowaniu należy stwierdzić, iż znaczenie sieci społecznych w kontekście przedsiębiorczości zostało silnie zaakcentowane w literaturze przedmiotu (por.: LARSON 1992; LARSON I STARR 1993; KRACKHARDT 1995; HITE I HESTERLY 2001; LIAO I WELSCH 2003; HITE 2005; AARSTAD, HAUGLAND I GREVE 2010). Sieci społeczne postrzegać można jako część kapitału społecznego. Najnowsze studia w tym zakresie przyczyniły się do rozszerzenia teorii kapitału społecznego, ukierunkowując ją na problematykę jego znaczenia i roli w przedsiębiorczości (HUANG I WANG 2013). Analiza literatury skłania także do stwierdzenia, iż sieci prywatnych, nieformalnych powiązań 
przedsiębiorców otwierają dostęp do zasobów, które w warunkach nieistnienia owych sieci byłyby nieosiągalne (OSTGAARD I BIRLEY 1994). Istnieje także ogólne porozumienie co do faktu, iż wysoki poziom kapitału społecznego, zbudowanego na bezpośrednich kontaktach często wspiera przedsiębiorców w pozyskiwaniu dostępu do funduszy venture capital, źródeł kluczowej informacji i potencjalnych klientów (CHISHOLM I NiELSEN 2009). Sieci społeczne pozwalają zatem przedsiębiorcom na pozyskanie dostępu do wartościowych zasobów, które często niedostępne są dla nich $\mathrm{w}$ inny sposób $\mathrm{z}$ powodu wysokiego kosztu. Sieci również mogą pozwolić przedsiębiorcom na pozyskanie dostępu do takich zasobów jak finansowanie, informacje i motywacja, a także wpływać na legitymizację nowych przedsięwzięć (NOWIŃSKI I RIALP 2015).

Zdecydowanie zatem stwierdzić należy, iż potencjał tkwiący $w$ sieciach osobistych przedsiębiorcy to zasób szczególnych możliwości i czynnik wpływający w sposób pozytywny na efektywność przedsiębiorstwa. Kontakty przedsiębiorcy $\mathrm{z}$ aktorami pochodzącymi z jego otoczenia generują wartościowe, wielowątkowe informacje $\mathrm{i}$ wiedzę, które odpowiednio zinterpretowane i wykorzystane w procesie przedsiębiorczego zarządzania przyczyniają się do wzrostu wielowymiarowo postrzeganej efektywności firmy.

\section{Bibliografia}

1. Aarstad J., Haugland S.A., Greve A. 2010. Performance spillover effects in entrepreneurial networks: assessing a dyadic theory of social capital. "Entrepreneurship Theory \& Practice" 34(5). s. 1003-1019.

2. ACQUAAH M. 2011. Business Strategy and Competitive Advantage in Family Businesses in Ghana: the Role of Social Networking Relationships. "Journal of Developmental Entrepreneurship" 16(1). s. 103-126.

3. Ahuja G. 2000. Collaboration Networks, Structural Holes, and Innovation: A Longitudinal Study. "Administrative Science Quarterly" 45(3). s. 425-455.

4. ANDERSON A.R., JACK S.L., DODD S.D. 2005. The role of family members in entrepreneurial networks: Beyond the boundaries of the family firm. "Family Business Review" 18(2). s. 135- 154.

5. BARBER B. 1995. All Economies Are Embedded: The Career of the Concept and Beyond. "Social Research" 62(2). s. 387-413.

6. BoISSEVAIN J. 1974. Friends of friends: Networks, manipulators and coalition. Blackwell. Oxford.

7. Bourdieu P. 1997. The Forms of Capital, [w:] A. H. Halsey, H. Lauder, P. Brown, A S. Wells [red.]: Education: Culture, Economy, Society, Oxford University Press. Oxford.

8. BRATNICKI M. 2004. Przedsiębiorczość organizacyjna: imperatyw, dialektyka, mity i dynamika deformacji, [w:] J. Rokita, W. Grudzewski (red.), Przedsiębiorczość 
a zarządzanie korporacjami. Górnośląska Wyższa Szkołą Handlowa im. Wojciecha Korfantego. Katowice. s. 23-49.

9. BRINK T. 2011. What connections in networks of private entrepreneurs are related to growth. "Journal of Depopulation and Rural Development Studies" 11. s. 57-82.

10. BURT R.S. 1995. Structural Holes: The Social Structure of Competition. Harvard University Press. Boston, MA.

11. Butler, J.E., BROWN, B., CHAMORNMARN 2003. W., Informational networks, entrepreneurial action and performance. "Asia Pacific Journal of Management" 20. s. 151-174.

12. Castilla E.J., Hwang H., Granovetter E., Granovetter M. 2000. Social Networks in Silicon Valley, [w:] Lee, C.-M., W.F. Miller, M.G. Hancock, H.S. Rowen (red.) The Silicon Valley edge: A habitat for innovation and entrepreneurship. Stanford. Calif: Stanford University Press.

13. Chisholm A.M., Nielsen K. 2009. Social capital and the resource-based view of the firm. "Int. Stud. Manag. Organ." 39(2). s. 7-32.

14. DANIK L., ŻUKOWSKA J. 2011. Czynniki wplywające na sukces kooperacji polskich przedsiębiorstw $w$ innowacjach (w przekroju branżowym). "Prace Naukowe Uniwersytetu Ekonomicznego we Wrocławiu. Problemy regionalizmu i globalizacji" 221, s. 123-136.

15. DiMaggio P., Zukin S. 1990. Structures of Capital. The Social Organization of the Economy. Cambridge University Press.

16. DOLlinger M.J. 1985. Environmental contacts and financial performance of the small firm. "Journal of Small Business Management" 23(1). s. 24-30.

17. Dubini P., AldRICH H. 1991. Personal and extended networks are central to the entrepreneurial process. "Journal of Business Venturing" 6(5). s. 305-331.

18. DYER L., Ross C. 2008. Seeking advice in a dynamic and complex business environment: impact on the success of small firms. "Journal Of Developmental Entrepreneurship" 13(2). s. 133-149.

19. ELLIS P. 2000. Social ties and foreign market entry. "Journal of International Business Studies" 31(3). s. 443-469.

20. Florin J., LubatKin M., W. Schulze 2003. A social capital model of high growth ventures. "Academy of Management Journal" 46(3). s. 374-384.

21. GRANDI A., GRIMALDI R. 2003. Exploring the Networking Characteristics of New Venture Founding Teams: A Stdy of Italian Academic Spin-off. "Small Business Economics" 21(4). s. 329-341.

22. Granovetter M. 1973. The Strength of Weak Ties. "American Journal of Sociology" 78(6). s. 1360-1380.

23. Granovetter M. 1985. Economic action and social structure: A theory of embeddedness. "American Journal of Sociology" 91(3). s. 481-510.

24. GREVE A., SAlAFF J.W. 2003. Social networks and entrepreneurship. "Entrepreneurship: Theory and Practice" 28(1). s. 1-22 .

25. GudKOVA S. 2008. Rozwój małych przedsiębiorstw. Wiedza, sieci osobistych powiązań, proces uczenia się. Wydawnictwa Akademickie i Profesjonalne. Warszawa.

26. Hamill L., Gilbert N. 2010. Simulating Large Social Networks In Agent-Based Models: A Social Circle Model. "Emergence: Complexity \& Organization" 12(4). s. 78-94. 
27. HITE J.M. 2005. Evolutionary processes and paths of relationally embedded network ties in emerging entrepreneurial firms. "Entrep. Theory Pract." 29(1). s. 113-144.

28. Hite J.M., HeSTERLY W.S. 2001. The evolution of firm networks: from emergence to early growth of the firm. "Strateg. Manag. J." 22(3). s. 275-286.

29. HitT M.A., IRELAND R.D., CAMP S.M., SEXTON D.L. 2001. Strategic entrepreneurship: Entrepreneurial strategies for wealth creation. "Strategic Management Journal" 22(special issue). s. 479-491.

30. HitT M.A., IRELAND R.D., CAMP S.M., SEXTON D.L. 2002. Strategic entrepreneurship: Integrating entrepreneurial and strategic management perspectives.[w:] M.A. Hitt, R.D. Ireland, S.M. Camp, D.L. Sexton, (red.), Strategic entrepreneurship: Creating a new integrated mindset. Blackwell Publishers, Oxford, U.K, s. 1-16.

31. Hormiga, E., Batista-CAnino, R.M., SAnchez-Medina, A. 2011. The impact of relational capital on the success of new business start-ups. "Journal of Small Business Management" 49(4), s. 617-638.

32. HuAng K.-P, WANG K.Y. 2013. The Moderating Effect of Social Capital and Environmental Dynamism on the Link between Entrepreneurial Orientation and Resource Acquisition, "Quality and Quantity" s. 1617-1628.

33. Huning T.M., BRYANT P.C., HOLT M.K. 2015. Informal Social Networks In Organizations: Propositions Regarding Their Role In Organizational Behavior Outcomes. "Academy Of Strategic Management Journal" 14(1), s. 20-29.

34. JACK S. 2005. The Role, Use and Activation of Strong and Weak Network Ties: A Qualitative Analysis. "Journal Of Management Studies" 42(6), s. 1233-1259.

35. JÄMsÄ P., TÄHTINEN J., RYAN A., PALlARI M. 2012. Sustainable SMEs network utilization: the case of food enterprises. "Journal of Small Business and Enterprise Development" 18(1), s. 143.

36. JOHANNISSON B. 1990. Economics of overview - guiding the external growth of small firms. "International Small Business Journal" 9, s. 32-44.

37. Julien P.A., ANDRIAMBeloson E., RAMANGALAHY C. 2004. Networks, weak signals and technological innovations among SMEs in the land-based transportation equipment sector. "Entrepreneurship and Regional Development" 16(4), s. 251-269.

38. KENT P. 1994. Management advisory services and the financial performance of clients. "International Small Business Journal" 12(4), s. 45-58.

39. KRACKHARDT D. 1995. Entrepreneurial opportunities in an entrepreneurial firm: Astructural approach. "Entrep. Theory Pract." 19(3), s. 52-69.

40. KRUEGER N.F., BRAZEAL D.V. 1994. Entrepreneurial potential and potential entrepreneurs. "Entrepreneurship theory and practice" 18, s. 91-91.

41. KWAŚNIEWICZ W. (red.) (1998), Encyklopedia Socjologii. Oficyna Naukowa. Warszawa.

42. LARSON A. 1992. Network Dyads in Entrepreneurial Settings: A Study of the Governance of Exchange Relationships. "Administrative Science Quarterly" 37(1), s. 76-104.

43. LARSON A.A., StARR J.A. 1993. A Network Model of Organization Formation. "Entrepreneurship Theory and Practice" 17(2), s. 5-15.

44. LAU, C.M., BRUTON, G.D. 2011. Strategic orientations and strategies of high technology ventures in two transition economies. "Journal of World Business" 46, s. 371-380. 
45. Laumann E.O., GalaskiewiCZ J., Marsden P.V. 1978. Community structure as interorganizational linkages. "Annual Review of Sociology", 4, s. 455-484.

46. Lechner C., Dowling M., WelPE I. 2006. Firm networks and firm development: The role of the relational mix. "Journal of Business Venturing" 21(4), 2006, s. 514-540.

47. LEMAŃSKA-MAJDZIK A., OKRĘGLICKA M., Determinants and Areas of an Organisation's Success - Literature Review, International Academic Conference on Management, Economics and Marketing (IAC-MEM 2015), Vienna, Austria, s. 32-42.

48. LIANXI Z., WEI-PING W., XUEMING L. 2007. Internationalization and the performance of born-global SMEs: The mediating role of social networks. "Journal of International Business Studies" 38(4), s. 673-690.

49. Manolova T.S., CARTER N.M., MAnev I.M., Gyoshev B.S. 2007 The differential effect of men and women entrepreneurs' human capital and networking on growth expectancies in Bulgaria. "Entrepreneurship: Theory and Practice" 31(3), s. 407-426.

50. MitChELl J.C. 1973. Networks, norms and institutions [w:] J. Boissevain, J.C. Mitchell (red.), Network analysis studies in human interaction. Mouton and Co., Netherlands, s. 15-36.

51. NELSON R. 1988. Social network analysis as an intervention tool. Group and Organization Studies, 13 (1), s. 40.

52. NogAlsKI B., NIEWIADOMSKI P. 2014. Dopasowanie zasobowe jako warunek elastyczności produktowej i determinanta konkurencyjności zakładu wytwórczego - ocena istotności wymagań, [w:] J. Stachowicz, M. Nowicka-Skowron, L.A. Voronina (red.), Rozwój organizacji $i$ regionu wyzwaniem dla ekonomii $i$ nauk o zarzadzaniu, Wydawnictwo „Dom Organizatora”, Toruń, s. 225-249.

53. Nowiński W., RiAlP A. 2015. The Impact of Social Networks on Perceptions of International Opportunities. "Journal of Small Business Management" artykuł w druku, DOI: 10.1111/jsbm.12149.

54. OLESIŃSKI Z. 2010. Zarządzanie relacjami międzyorganizacyjnymi, Wydawnictwo C.H. Beck, Warszawa.

55. OstgandD T.A., BIRley S. 1994. Personal networks and firm competitive strategy: a strategic or coincidental match? "Journal of Business Venturing" 9(4), s. 281- 305.

56. OWEN-SMith J., POWELL W.W. 2004. Knowledge networks as channels and conduits: The effects of spillovers in the Boston biotechnology community. "Organization Science", 15, s. 5-21.

57. OZGEN E., BARON R.A. 2007. Social Sources of Information in Opportunity Recognition: Effects of Mentors, Industry Networks, and Professional Forums. "Journal of Business Venturing" 22(2), s. 174-192.

58. POLANYI K. 2010. Wielka transformacja. Wydawnictwo Naukowe PWN. Warszawa.

59. QIAN S., KEMELGOR B.H. 2013. Boundaries of Network Ties in Entrepreneurship: How Large is Too Large? "Journal Of Developmental Entrepreneurship" 18(4), s. 1-19.

60. RAuch, A., Rosenbusch, N., Unger, J., \& Frese, M. 2016. The effectiveness of cohesive and diversified networks: A meta-analysis. "Journal of Business Research" 69(2), s. 554568. 
61. Ripollés M., BlesA A. 2005. Personal networks as fosterers of entrepreneurial orientation in new ventures. "The International Journal of Entrepreneurship and Innovation" 6(4), s. 239-248.

62. ROWLEY T., BEHRENS D., KRACKHARDT D. 2000. Redundant governance structures: An analysis of structural and relational embeddedness in the steel and semiconductor industries. "Strategic Management Journal" 21, s. 369-386.

63. SARNOWSKI T. 2013. Budowanie sieci relacji społecznych dla wzrostu potencjatu przedsiębiorstwa. Analiza przypadku. "Przedsiębiorczość i Zarządzanie". Wydawnictwo SAN, Tom XIV, Zeszyt 12, Cz. III, s. $61-69$.

64. Shane S., Venkataraman S. 2000. The Promise of Entrepreneurship as a Field of Research. "Academy of Management Review" 25(1), s. 217-226.

65. SKALIK J. 2010. Formy wzmocnienia kluczowych czynników sukcesu matych $i$ średnich przedsiębiorstw, [w:] K. Jaremczuk (red.), Uwarunkowania przedsiębiorczości. Różnorodość $i$ jedność, Tom II. Państwowa Wyższa Szkoła Zawodowa im. Prof. Stanisława Tarnowskiego w Tarnobrzegu. Tarnobrzeg. s. 173-182.

66. SŁAwECKI B. 2011. Zatrudnianie po znajomości. Kapital społeczny na rynku pracy. Wydawnictwo C.H. Beck. Warszawa.

67. StachOwICZ J. 2011., Globalne sieci przeplywu kapitału, wiedzy oraz wartości jako kluczowe wyzwanie w zarzadzaniu przedsiębiorstwami, "Zeszyty Naukowe" nr 9. Polskie Towarzystwo Ekonomiczne. Kraków. s. 201-214.

68. StachOWICZ J. 2015. Przedsiębiorczość technologiczna kluczowa siła rozwoju przedsiębiorstw wysokich technologii. "Zeszyty Naukowe Politechniki Śląskiej, Organizacja i Zarządzanie" 83(1941) s. 627-639

69. STAM W., ElFRING T. 2008. Entrepreneurial orientation and new venture performance: The moderating role of intra- and extraindustry social capital. "Academy of Management Journal" 51(1), s. 97-112.

70. TOMSKI P. 2016. Sieć społeczna przedsiębiorcy w teorii i praktyce zarządzania małą firmą. Wydawnictwo Wydziału Zarządzania Politechniki Częstochowskiej. Częstochowa 2016.

71. UZZI B. 1996. The Sources and Consequences of Embeddedness for the Economic Performance of Organizations: The Network Effect. "American Sociological Review" 61, s. 674-698.

72. VENKATARAMAN S. 1997. The distinctive domain of entrepreneurship research. "Advances in Entrepreneurship Research, Firm Emergence and Growth" 3(1), s. 119-138.

73. VISSA B., CHACAR A.S. 2009. Leveraging ties: The contingent value of entrepreneurial teams_external advice networks on Indian software venture performance. "Strategic Management Journal" 30(11), s. 1179-1191.

74. WATSON J. 2007. Modeling the relationship between networking and firm performance. "Journal of Business Venturing" 22(6), s. 852-874.

75. WeSt G.P., NOEL T.W. (2009), The impact of knowledge resources on new venture performance. "Journal of Small Business Management" 47(1), s. 1-22. 